\title{
ARTUR BANASZAK
}

Alcide De Gasperi University

of Euroregional Economy, Józefów, Poland

https://orcid.org/0000-0003-3657-3866

\section{The right to education - the necessary condition of social security}

\begin{abstract}
The right to education is one of the most important human rights. It is a basic right not a privilege. The subject of this study is to present the right of educational as the necessary condition for the social safety and security understood as the state in which a person is able to survive and to develop. In this paper, I will analyze the content of right to education, then I will show how this right is implemented in different countries. Finally, I will analyze, the situation related to coronavirus pandemic state as the barrier of implementation of this right.
\end{abstract}

Keywords: rights to education, child's right, social safety, pandemic CIVID19

\section{Introduction}

The right to education maybe consider as one of the most crucial human rights. It is proven that high quality education makes human life much easier and gives a lot of opportunities. It can be said that education is one of the human needs which is helping to satisfy many other needs faced by people. In short, the life of educated people is easier and it has higher quality.

It is also one of the most basic human rights which must be satisfied in order to get the sense of social security which can be 
understand as the possibility to survive and to developed. In short, the satisfaction of right to education is necessary condition to full development of a human being.

The subject of this study is to present the right of education as a necessary condition of social security. In this study, I would like to show the link and the relation between human need to education, the human right to education and the social safety and security. After showing this connection, I will present some of the selected documents of the international regulation on the right to education. Then, I would like to show some examples of implementation of this right in the real world. In addition, I will give some remarks on the situation of access to education in the crises situation which we are facing currently - namely during the pandemic of coronavirus.

\section{The right to education and social safety}

A human being in order to full development need to satisfy his or her different needs. Human needs can be understood in many different ways. One of them is traditional understanding and classification of human need given by psychologist - Abraham Maslow ${ }^{1}$ and his hierarchy of needs (the piramid of meeds). According to this theory, there are five levels of human needs. Starting from basic needs (physiological and safety) through psychological needs (belongings and lobe as well as esteem needs) and finishing with self-fulfillment needs (self-actualization), this theory is proving that in order to full development of human being, satisfaction of each and every need is necessary.

\footnotetext{
1 See: MASLOW, A. Human Motivation, pp. 370-396.
} 
To satisfy the need of self-actualization, it is necessary to achieve one's full potentials including creativity activities. In order to obtain this goal, we need several things, among other - education. Therefore, we may state that the need to education is one of human needs which need to be satisfy

It was already said that human needs should be satisfy. Therefore, it is necessary to develop the "tool" or kind of "application" which may help in the process of fulfilling human needs. According to $M$. Sitek, taking care of observance of human rights is the best answer and the best remedies to human needs. In this case, the human needs are the starting points and the human rights based on those particular needs are the answer. Protection of human rights seems to be a very important issue while we are talking about the process of satisfying human needs. ${ }^{2}$ Therefore, there is strong link and relation between the need to education and the right to education. It may be said that the protection and observance of human right to education is a solution in the process of satisfying human need to education and consequently leads to assurance that human being will be able to achieve his or her full potential and development.

It is also important to note that for full development, human being needs to have the feeling of security, especially - social security. There are many definition and description of this term. From the positive point of view, we can use here the definition given by A Skarbacz and S. Sulowski where social safety could be understood as "protection of the existential basis of human life, ensuring the possibility of satisfying individual needs (material and spiritual) and fulfilling life aspirations by creating conditions

${ }^{2}$ More on relation between human need and human rights: SITEK, M. Prawa (potrzeby) człowieka w ponowoczesności, pp. 27-48. 
for work and study, health protection and pension guarantees"3. While from the negative point of view, we can use the description of M. Such-Pyrgiel and K. Dziurzyński, where social safety is described as some kind of protection against various social risks and other situations which do not allowed a person to take care of his or her needs ${ }^{4}$. Good summary of different definitions is made by description of social safety given by W. Pokruszyński who is stating that security and especially social security it is the ability to survive and develop. ${ }^{5}$

Based on those descriptions of the term of social security, we can say that it is the state where human being has a chance to life and to develop him or herself. It means that satisfying of all human needs is necessary for sense of social safety. It also means that the access to education guarantees by right to education is necessary to have social security.

In addition, we need to see the education not only from the perspective of self-actualization needs. Having good education give more chance to get good job and to earn financial resources which help human being to satisfy also other needs such as food, accommodation, taking care of family, going to holidays, getting good position in work place. Therefore, the right to education and the social safety are connected. Human being needs education in order to provide satisfaction of each and every need and consequently to have chance to survive and to developed ${ }^{6}$.

${ }^{3}$ SKRABCZ, A. SULOWSKI, S. Bezpieczeństwo społeczne. Pojęcia, uwarunkowania, wyzwania, p. 7.

4 Such-Pyrgiel, M., Dziurzyński, K. Bezpieczeństwo społeczne. Leksykon Bezpieczeństwo. Wybrane pojęcia, p.141 and pp. 143-144

5 Pokruszyński, W. Filozoficzne aspekty bezpieczeństwa, p. 39

6 More on reletion between education and social safety: BANASZAK, A. Oświata i edukacja a bezpieczeństwo społeczne, pp. 139-158. 


\section{The right to education in International regulations}

The right to education is guaranteed by different international regulations. Those provisions have different legal power as well as they cover the entire world or just particular region ${ }^{7}$. It is impossible to discuss all of them in details. Therefore, I would like to present just selected examples and then give the list of rest of them.

The first international codification of the right to education is indirectly found in the Declaration - the Rights of the Child - Geneva Declaration adopted in 1923 by the International Save the Children Union in Geneva and a year later, proclaimed in 1924 by the League Nations. There we can find the article 1 as well as 4 and 5 which are consider indirect pointing to the need of education: "The child must be given the means requisite for its normal development, both materially and spiritually" (art. 1), "The child must be put in a position to earn a livelihood, and must be protected against every form of exploitation" (art. 4) and "The child must be brought up in the consciousness that its talents must be devoted to the service of its fellow men" (art. 5). ${ }^{8}$ The issues mentioned in Declaration such as normal developed or ability to earn living are related to education which may provide such things.

The Universal Declaration of Human Rights is the next very important document which should be mentioned here. In the article 26, we can read that: "Everyone has the right to education. Education shall be free, at least in the elementary and fundamental stages. Elementary education shall be compulsory.

\footnotetext{
7 More on the legal bases of human right to education: Beiter, K.,D.. The Protection of the Right to Education by International Law.

8 Geneva Declaration of 1923.
} 
Technical and professional education shall be made generally available and higher education shall be equally accessible to all on the basis of merit. Education shall be directed to the full development of the human personality and to the strengthening of respect for human rights and fundamental freedoms..." This statement in very direct way is showing the importance of education as well as is stating that education on the basic level should be free and compulsory.

United Nations declaration has rather low legal power. Much stronger is another document which was adopted in 1966 - the International Covenant on Economic, Social and Cultural Rights. This regulation in the article 13 is stating, among others, that: "The States Parties to the present Covenant recognize the right of everyone to education. They agree that education shall be directed to the full development of the human personality and the sense of its dignity, and shall strengthen the respect for human rights and fundamental freedoms. They further agree that education shall enable all persons to participate effectively in a free society, promote understanding, tolerance and friendship among all nations and all racial, ethnic or religious groups, and further the activities of the United Nations for the maintenance of peace" and in paragraph $2 a$ is adding that: "The States Parties to the present Covenant recognize that, with a view to achieving the full realization of this right: Primary education shall be compulsory and available free to all" 10 . Basically, we have here the repetition on the statement from Universal Declaration but this type of legal document has banding power to the courtiers which signed it.

9 UNITED NATION ORGNIZATION. Universal Declaration of Human Right.

10 International Covenant on Economic, Social and Cultural Rights 
The right to education is also guarantee by the Declaration of the Rights of the Child from 1959 where the principle 7 says that: "The child is entitled to receive education, which shall be free and compulsory, at least in the elementary stages. He shall be given an education which will promote his general culture and enable him, on a basis of equal opportunity, to develop his abilities, his individual judgment, and his sense of moral and social responsibility, and to become a useful member of society"11.

Also, the Convention on the Rights of the Child from 1989 we have statement about right to education. In the article 28 we can read "States Parties recognize the right of the child to education, and with a view to achieving this right progressively and on the basis of equal opportunity, they shall, in particular: (a) Make primary education compulsory and available free to all; (b) Encourage the development of different forms of secondary education, including general and vocational education, make them available and accessible to every child, and take appropriate measures such as the introduction of free education and offering financial assistance in case of need; (c) Make higher education accessible to all on the basis of capacity by every appropriate means; (d) Make educational and vocational information and guidance available and accessible to all children; (e) Take measures to encourage regular attendance at schools and the reduction of drop-out rates". Also, there is article 29 which explains that: "1. States Parties agree that the education of the child shall be directed to: (a) The development of the child's personality, talents and mental and physical abilities to their fullest potential"12.

11 Declaration of the Rights of the Child.

12 Convention on the Rights of the Child 
There are also some documents which have regional range. One of them is the Charter of Fundamental Rights of the European Union from 2000. The article 14 states that: "1. Everyone has the right to education and to have access to vocational and continuing training. 2. This right includes the possibility to receive free compulsory education"13.

As it was said at the beginning of this part - the cited and described document are not the only ones talking about one of the most important human right which is right to education. The full list of these documents is much longer and includes regulations, provisions, declarations, protocols, conventions, recommendations and other types of materials which cover the entire world or just particular continents or regions. There are ${ }^{14}$ :

\section{UN Declarations}

Universal Declaration of Human Rights, 1948;

Declaration on the Rights of the Child, 1959;

Declaration on the Rights of Persons Belonging to National or

Ethnic, Religious and Linguistic Minorities, 1992;

Declaration on the Rights of Indigenous Peoples, 2007;

Declaration on Human Rights Education and Training, 2011.

\section{UN Conventions}

Convention on the Rights of the Child, 1989;

Convention relating to the Status of Refugees, 1951;

International Convention on the Elimination of All Forms of Racial Discrimination, 1965;

\footnotetext{
${ }^{13}$ Charter of Fundamental Rights of the European Union.

14 UNESCO. The right to education. Law and Policy Review Guidelines, pp. 49-51.
} 
International Covenant on Economic, Social and Cultural Rights, 1966;

International Covenant on Civil and Political Rights, 1966;

Convention on the Elimination of All Forms of Discrimination against Women, 1979;

International Convention on the Protection of the Rights of All

Migrant Workers and Members of their Families, 1990;

Convention on the Rights of Persons with Disabilities, 2006.

\section{UNESCO Constitution, Conventions and Recommendations}

Constitution of UNESCO, 1945;

Convention against Discrimination in Education, 1960;

Convention on Technical and Vocational Education, 1989;

Recommendation against Discrimination in Education, 1960;

Recommendation concerning the Status of Teachers, 1966;

Recommendation concerning Education for International

Understanding, Co-operation and Peace and Education

relating to Human Rights and Fundamental Freedoms, 1974;

Recommendation on the Development of Adult Education, 1976;

Recommendation on the Recognition of Studies and Qualifications

in Higher Education, 1993;

Recommendation concerning the Status of Higher-Education

Teaching Personnel, 1997;

Revised Recommendation concerning Technical and Vocational Education, 2001.

\section{Other instruments of human rights framework}

Hamburg Declaration on Adult Learning, 1997;

World Declaration on Education for All, Jomtien, Thailand, 1990;

Declaration and Integrated Framework of Action on Education for

Peace, Human Rights and Democracy, 1994; 
Salamanca Statement on Principles, Policies and Practice in Special Needs on Education, 1994;

Delhi Declaration, Education for All Summit, 1993;

World Declaration on Higher Education for the Twenty-first Century, 1998;

World Programme for Human Rights Education (2005-ongoing); Dakar Framework for Action, World Education Forum, Dakar, Senegal, 2000;

Universal Declaration on Cultural Diversity, 2001.

\section{ILO Conventions}

Convention on the minimum age for employment (convention No. 138, adopted the 6 June 1973);

Worst Forms of Child Labour Convention (convention No. 182, adopted on 17 June 1999);

Indigenous and Tribal Peoples Convention, 1989 (Convention No. 169, adopted on 27 June 1989.

\section{Regional Systems}

African

African Charter on Human and People's Rights, 1981;

African Charter on the Rights and Welfare of the Child, 1990;

Protocol to the African Charter on Human and Peoples' Rights on the Rights of Women in Africa, 2003.

\section{American}

Charter of the Organization of American States, 1948;

American Declaration of the Rights and Duties of Man, 1948;

American Convention on Human Rights, 1969;

Protocol of San Salvador: Additional Protocol to the American Convention on Human Rights in the Area of Economic, Social, and Cultural Rights, 1988; 
Inter-American Convention on the Prevention, Punishment and Eradication of Violence against Women, 1994.

$\underline{\text { Arab }}$

Arab Charter on Human Rights, 2004.

Asian

ASEAN Human Rights Declaration, 2012.

European

European Union:

Charter of Fundamental Rights, 1999.

Council of Europe:

Convention for the Protection of Human Rights and Fundamental

Freedoms, 1950, and its Protocols 1, 4, 6, 7, 11 and 12;

European Social Charter, 1961, 1999;

European Charter for Regional or Minority Languages, 1992;

Framework Convention for the Protection of National Minorities, 1995;

Charter on Education for Democratic Citizenship and Human Rights Education, 2010.

\section{General Comments adopted by the UN Treaty bodies including notably:}

General comment No. 3 (1990) adopted by the Committee on Economic, Social and Cultural Rights (CESCR) on The nature of States parties' obligations (art. 2 (1));

General comment No. 9 (1998) adopted by the Committee on Economic, Social and Cultural Rights (CESCR) on The domestic application of the Covenant,

General comment No. 11 (1999) adopted by the Committee on Economic, Social and Cultural Rights (CESCR) on Plans of action for primary education (art. 14); 
General comment No. 13 (1999) adopted by the Committee on Economic, Social and Cultural Rights (CESCR) on The right to education (art. 13);

General comment No. 20 (2009) adopted by the Committee on Economic, Social and Cultural Rights (CESCR) on NonDiscrimination in Economic, Social and Cultural Rights (art. 2 (2));

General comment No. 1 (2001) adopted by the Committee on the Rights of the Child (CRC) on the aims of education (art. 29 (1));

General comment No. 7 (2005) adopted by the Committee on the Rights of the Child (CRC) on Implementing Child Rights in Early Childhood; and

General comment No. 9 (2006) adopted by the Committee on the Rights of the Child (CRC) on the rights of children with disabilities.

Above described and mentioned documents clearly state that the right to education is firmly entrenched in the provisions of international law. Numerous documents guarantee the right to education, which should be free and compulsory at the basic level ${ }^{15}$.

\section{Implementation of the right to education in the world}

The fact that the right to education is written in different legal regulations does not mean that in real life everyone has free access to schools and other types of educational institutions.

15 More on right to education as the answer to human need to education: SITEK, M. Prawa (potrzeby) człowieka w ponowoczesności, pp. 286-292. 
There are many reasons when the right to education is disturbed or people have no possibility to get education. In contemporary world the reasons which caused problem in the area of free access to education are poverty, luck of taking good care of children, the necessity of conducting work by children as well as different military conflicts ${ }^{16}$.

Taking about the reasons of not having access to education, we have to point out to few issues. First of all, we should mention the inequality between countries and different regions of the world. This inequality concerns first of all access to financial resources and, consequently, various kinds of modern achievements. Observing world, we can see that some of the courtiers are very reach while other have not enough resources to satisfy even the basic needs. Due to this inequality between countries and different regions of the world. This inequality concerns primarily access to financial resources and, consequently, various types of modern achievements. The result of this is marginalization of some countries and entire regions and consequently, many people from these areas have no access to education ${ }^{17}$.

Different statistical data is showing that in many parts of the world, children are deprived of access to education and thus their full intellectual and personal development is at risk. There are some UNESCO and other institutions reports which are saying that in 2018 , around 262 million children and youths were out of school ${ }^{18}$.

The data is showing that currently, more 750 million adults in the world are illiterate - they are not able to read and write.

16 More on military conflicts disturbing access to education: Banaszak, A. The military and terroristic conflict as a factor preventing the implementation of human right of access to education, pp. 69-84.

17 UNICEF. Global Annual Results Report 2018, pp. 10-16.

18 UNICEF. Global Annual Results Report 2018, pp. 10-16 
It means that they did not have access to education and schooling system. Some regions are specially touched by those problems. For example, in Sub-Sahara region, 72 million people are deprived of the access to primary education. Very similar situation is in Central and Eastern Asia. ${ }^{19}$ There are also problems with the access to pre-primary education. UNESCO reports are showing that currently around 175 million children are facing this problem. Also, due to military conflicts and terrorism, 27 million people cannot attend the schools. ${ }^{20}$

In addition, there is a big problem with gender discrimination in the area of access to education. Data is showing that, girls and women make $54 \%$ of non-schooling population. For example, in Sub-Sahara region, 12 million of girls are at risk to never attend the school. In Yemen, more than $80 \%$ of grills will never get a chance to receive any kind of education. In such countries like Afghanistan or Somalia, the situation seems to be even worse ${ }^{21}$.

There are many problems with the protection of right to education and the same time, there are a lot of activities to improve the situation. UNESCO and other institution are sending financial resources as well as human recourses to help those countries which are not able to deal alone with these problems ${ }^{22}$.

There are also numerous initiatives which helped. As the example, we can show here the initiative which is popular in Poland and which is called - "distance adoption". This initiative is about taking care of children in developing countries by people from Poland. Those people are adopting a child are covering the cost of education. There are so many these activities done

\footnotetext{
19 HUMANIUM. Right to Education : Situation around the world

20 UNICEF. Global Annual Results Report 2018, pp. 10-16

21 HUMANIUM. Right to Education : Situation around the world

22 UNICEF. Global Annual Results Report 2018, pp. 2-8.
} 
by different non-profit organization but also by churches or religious congregations. One of them is programme implemented by Missionary Oblates of Immaculate Mary called - "Mission - school". Children from the countries where those priest work, are helped by Polish families who pay for education in such countries like Madagascar, India, Bangladesh or Nepal. In 2020, 750 children from different part of the world were financed by "adoption parents from Poland" in regard of this programme ${ }^{23}$. Describe programme is only an example of many similar projects done by different organization in Poland but also in other countries.

UNESCO monitoring reports are showing that the implementation of one of the most important human rights - right to education is better every year. For example, in 2017 it was 264 million children and youths without access to education and in 2018, the number decreased to 262 million. This organization as well as others institutions, among them non-profit organizations and religious organizations related to different churches have done a lot of work in this area in order to improve the situation. However, the scenario is still not good and much more must be done.

\section{The right to education and the state of pandemic covid 19}

It was already presented that free access to education may be disturbed by different obstacles. One of them is the state of pandemic related to the spread of virus covid-19 which cased the disease. On $11^{\text {th }}$ March 2020, the World Health Organization

${ }^{23}$ More on this topic: MISJONARZE OBLACI MN at: https://adopcjamisyjna. misyjne.pl. (access: 01.09.2020). 
called the state of pandemic ${ }^{24}$. It was a reaction to huge spread of the virus covid-19 all over the world. The numbers of daily cases was growing dramatically. Particular countries in Europe but also in other part of the world were calling state of epidemic threat and then the state of epidemic. Based on this, people were told to stay at homes and consequently, the offices, business as well as schools and other education institutions were being closed.

In Poland and other European countries, the schools were closed since March 2020 and kids were able to come to classroom only after summer holidays (in August and September). In some places, there is still problem are educational institutions stayed closed. In most of the Europe and other developed countries, after short break, the learning process was continued as the distance or on-line learning. But, there are many places, where due to pandemic, children have not any access to education.

The statistical data showing the impact of pandemic COVID-19 on access to education from the global point of view is frightening. Due to pandemic, 1.6 billion students from 199 countries faced obstacles in access to education. In the world around $94 \%$ students were touched by the fact of closing educational institution. In less developed countries, the situation is even worse and the level is reaching as much as $99 \%$ students from pre-primary to tertiary education. In addition, almost 24 million students who are leaving in less developed countries may faced the situation that due to economic problems caused by pandemic, they will bot be able to comebac to school even after pandemic is gone ${ }^{25}$.

24 PAP. WHO ogłasza pandemię, at: https://www.mp.pl/pacjent/chorobyzakazne/koronawirus/koronawirus-aktualnosci/229137, who-oglasza-pandemie (access: 01.09.2020).

25 UNITED NATION. Policy Brief: Education during COVID-19 and beyond, pp. 2-3. 
In some countries, the education was moved to virtual reality and classes and other school activities we conducted as distance or on-line learaning. It means that children and youths were taking classes from home. This situation is ofcourse much better than being deprived of access at all but it does not mean the the entire process of on-line learning did not faced any problems.

First of all, even in well developed countries, there was a problem that some children "disappear" from educational system. The reson for such situation was that not everybody has access to IT technology and to the Internet. Also, i some families, there was no support for children in learning process and students were not able to get good quality education, even it was provided by schools. Only in Poland, which implamented compulsarry distance lerning, few procetage of students have never participaded in online classes. For example, in Warsaw, according to local gaverment data, 600 students have no acces to education in May 2020 (there are 235000 children in Warsaw schooling system). Accordig the teacher's union organization in Łódz,at some point of pandemic lockdown, almost $15 \%$ of students faced differet kind of problems with the access to good quality education in this city. ${ }^{26}$

Staying at home and not going to school brought also other problems related to the intelectual and personal development of children and youths. First of all, the problem of domestic violence was faced by children. Before pandemic, those children were control by school and they were staying outside of home. During pandemic, they need to stay all day long with parents

26 RADWAN, A. Pandemiczne dzieci nie chcą się uczyć. Uczniowie znikają w systemie zdalnej edukacji at: https://serwisy.gazetaprawna.pl/edukacja/ artykuly/1479122,zdalne-lekcje-uczniowie-dzieci-obowiazek-szkolny.html (access: 01.09.2020). 
or other pople who use violence againt them. In such situation there were not able to get proper education and focus on learnig materials. ${ }^{27}$

Using on-line resources as well as the Internet can also coused the problem related to cybersecurity. Children participating in online classes and having almost unlimitted nd uncontroled acces to the Internet, were exposed to various dangers in cyberspace. Thus, their right to security was compromised. The access to Internet and new IT technology gives the oportunity to mentain the access to education even in the crises situation such as pandemi. However, the Internet used without any control by children can be denger and brings a lot of harm to personal developement of children and to their sense of social security ${ }^{28}$.

Taking about the impact of pandemic covid-19 on the access to education, we have to also mention the problem of disable children. Because of their deficits, the access to schools and learning process is difficult even in normal times. During the pandemic, the situation was even worse. Many of them are not able to use computers and other devises. In many situation distance learning is not doing much good while is done for people with disabilities. Therefore, many of those children and youths were deprived of the right to education because of state of pandemic and lockdown which result in closing schools and other educational institution used by them ${ }^{29}$.

27 More on the problem of domestic violence: BOJARUNIEC, M. Intimate Partner Violence and UN activity on women rights protection, pp. 497-529.

${ }^{28}$ More on relation between human rights and cyberspace: FLOREK, I., EROGLU S. The need for protection of human rights in cyberspace, pp. 27-36.

29 RÓŻAŃSKI, M. Uczniowie ze specjalnymi potrzebami odcięci od nauki. Apel społeczników do ministra edukacji at: http://www.niepelnosprawni.pl/ledge/x/1009294 (access: 01.09.2020). 
Above mention short review of the situation related to impact of pandemic on the implementation of right to education is showing that many students faced and they are still facing a lot of problems with the access to good duality education.

\section{Conclusion}

The right to education is one of the most important human rights which guarantee that a human being will satisfy his or her basic needs and his or her full development will possible. The need to education should be satisfy because this is necessary condition to sense the social security.

There is very clear link and relation between education and the sense of social security. In order to survive and to have a chance to achieve one's full potential, it is necessary to get good education. The access to education not only provide a possibility to satisfy higher level needs such as self-actualization but also, educated person will have more chance to satisfy even his or her basic needs. Therefore we can say that human need to education is leading to the necessity of satisfying this need by protection of human right to education and this take us to possibility to experience the sense of social security.

The right to education is guarantee by numerous international provisions and regulations which strongly state that each and every human being should have the access to education which on the basic level should be free of charge as well as compulsory.

It also must be said that even rule and regulations guarantee the right to education, the situation in real world is not that good. There are many problems which make the access to education very difficult and still a lot of children and youths are deprived 
of this basic human right. In fact, there are a lot of different activities aimed on improving this situation but still much more must be done, especially in the regions which are less developed economically.

Also, it need to be state that current situation of pandemic caused by covid-19 make the scenario even worse and all these activities focused on stopping the spread of virus result in the fact that many students could not attend the school and have no access to education. The implementation of online classes and distance learning helped to some extend but not in each and every situation.

The right to education is one of the most important and basic human rights. It results from human needs to education and its satisfaction makes full development of the person passable.

\section{References:}

BANASZAK, A. (2013). Oświata i edukacja a bezpieczeństwo społeczne. w: M. Such-Pyrgiel (red.), Bezpieczeństwo społeczne w XXI wieku $\mathrm{w}$ ujęciu socjologicznym, pedagogicznym, prawnym i nauk o zarządzaniu (ss. 139-158). Józefów: Wydawnictwo Wyższej Szkoły Gospodarki Euroregionalnej im. Alcide De Gasperi, 2013. ISBN 978-83-6275-337-6.

BANASZAK, A. The military and terroristic conflict as a factor preventing the implementation of human right of access to education, in M. Sitek, G. Dammacco, M. Wójcicka (ed.) Human rights between war and peace - volume 2, 2014, pp. 69-84. ISBN 978-83-6238-354-2.

BEITER, K.,D. The Protection of the Right to Education by International Law. Leiden. Martinus Nijhoff Publisher, 2005. ISBN 978-66-1239646-5.

BOJARUNIEC, M. Intimate Partner Violence and UN activity on women rights protection. In: M. Mamiński, M. Rzewuski Contemporary problems of human right, Józefów: Wydawnictwo Wyższej Szkoły 
Gospodarki Euroregionalnej im. Alcide De Gasperi , 2019, pp. 497529.ISBN 978-83-8090-670-9.

Charter of Fundamental Rights of the European Union.

Convention on the Rights of the Child

Declaration of the Rights of the Child.

FLOREK, I., EROGLU S. The need for protection of human rights in cyberspace. In: Journal of Modern Science 3/42/2019, pp. 27-36. Geneva Declaration of 1923.

GRACA, T., SUCH-PYRGIEL, M., Prawa człowieka i ich upowszechnianie w strukturach różnych poziomów edukacji [in:] Parente F., Sitek B., Florek I. (ed.) Human rights in the functioning of public administration Prawa człowieka w funkcjo-nowaniu administracji publicznej, Józefów, 2018, 77-78. ISBN 978-83-6275-396-3.

HUMANIUM. Right to Education : Situation around the world International Covenant on Economic, Social and Cultural Rights MASLOW, A. Human Motivation. In: Psychological Review, 1943 (50). MISJONARZE OBLACI MN at: https://adopcjamisyjna.misyjne.pl. (access: 01.09.2020).

PAP. WHO ogłasza pandemię at: https://www.mp.pl/pacjent/chorobyzakazne/koronawirus/koronawirus-aktualnosci/229137, whooglasza-pandemie (access: 01.09.2020).

POKRUSZYNSKI, W. Filozoficzne aspekty bezpieczeństwa. Józefów: Wydawnictwo WSGE, 2011. ISBN 978-83-6275-313-0.

RADWAN, A. Pandemiczne dzieci nie chcą się uczyć. Uczniowie znikają w systemie zdalnej edukacji at: https://serwisy.gazetaprawna. pl/edukacja/artykuly/1479122,zdalne-lekcje-uczniowie-dzieciobowiazek-szkolny.html (access: 01.09.2020).

RÓŻAŃSKI, M. Uczniowie ze specjalnymi potrzebami odcięci od nauki. Apel społeczników do ministra edukacji at: http://www. niepelnosprawni.pl/ledge/x/1009294 (access: 01.09.2020).

SITEK, M. Prawa (potrzeby) człowieka w ponowoczesności. Warszawa: C.H.Beck Publishing House, 2016. ISBN 978-83-2558-922-6.

SKRABCZ, A. SULOWSKI, S. Bezpieczeństwo społeczne. Pojęcia, uwarunkowania, wyzwania. Warszawa: Elipsa, 2012. ISBN 978-837151-079-3. 
SUCH-PYRGIEL, M., DZIURZYŃSKI K. (2015). Bezpieczeństwo społeczne. Leksykon Bezpieczeństwo. Wybrane pojęcia. ed. P. Chodak. Józefów: WSGE Publishing House. ISBN 978-83-6275354-3.

UNESCO (2014). The right to education. Law and Policy Review Guidelines. Retrieve from https://unesdoc.unesco.org/ark:/48223/ pf0000228491 on 15.08.2020.

UNICEF. Global Annual Results Report 2018, pp. 10-16 UNITED NATION ORGNIZATION. Universal Declaration of Human Right. UNITED NATION. Policy Brief: Education during COVID-19 and beyond. 